\title{
Editorial
}

\section{Diarréia - fatores de risco associados ao óbito em crianças}

As enfermidades diarréicas representam um grande e grave problema de saúde pública, particularmente nos países subdesenvolvidos ou em desenvolvimento. Elas respondem por significativa taxa de morbimortal idade infantil nesses locais, situando-se como uma das principais causas de consultas médicas, de internações hospitalares, de desnutrição, de patologias outras associadas ou decorrentes e de óbitos em crianças de baixa idade.

Ao mesmo tempo que as medidas de política de saúde, saneamento básico, higienização geral e dos alimentos em particular, de cultura, de conhecimento das bases humanísticas e sociais vão sendo implementadas, observa-se uma drástica redução desses indicadores, o que pode ser observado nos países desenvolvidos nas últimas décadas.

A grande preocupação no trato das enfermidades diarréi cas direciona-se para a resolução do quadro agudo em primeira instância; isto posto, surgem, com toda ênfase, as circunstâncias que as desencadearam, quer do ponto de vista epidemiológico, quer social ou estritamente médico. Neste bojo, são vastos os estudos e seus frutos são notáveis e visíveis em todas as regiões do gl obo.
U m aspecto muito interessante surgiu com o artigo da Dra. J acy de Andrade et al, publicado neste número da Revista da AMB. Tratase de procurar e analisar os fatores de risco associados ao óbito de crianças acometidas de diarréia aguda e hospitalizadas. Nos centros hospitalares universitários, de excelência, como aquel e gerador do trabal ho em tel a, acreditamos até que os fatores de risco sejam cogitados com freqüência no trato com os pacientes infantis internados e os cuidados inerentes tomados constantemente.

No entanto, a comprovação inequívoca dos fatos, a sua documentação e divulgação assume um caráter de al erta aos pediatras de todas as regi ões, quaisquer que sejam os estágios de desenvolvimento. Assim, os autores apontam como fatores de risco associados ao óbito de crianças hospitalizadas com diarréia aguda: a idade inferior a seis meses, encontro de Escherichia coli entero-patogência em fezes, desnutrição protéi co-calórica III grau e intolerância alimentar.

\section{Flávio Adolfo Costa Vaz}

Professor titular de Pediatria da Faculdade de Medicina da Universidade de São Paulo. 